\title{
PERAN ORANG TUA DALAM MEMBANGUN KEPERCAYAAN DIRI PADA ANAK USIA DINI
}

\author{
Muzdalifah M. Rahman \\ STAIN Kudus, Jawa Tengah, Indonesia. \\ muzdakudus@gmail.com
}

\begin{abstract}
Abstrak
Masa emas (golden age) pada perkembangan pada usia pra sekolah harus menjadi perhatian yang serius di kalangan pendidik utama yaitu orang tua. Sebab masa ini adalah masa yang mudah membentuk keperibadian anak. Kajian ini berusaha menelusuri persoalan masa emas anak dalam perkembangannya dengan nelakukan kajian informasi kepustakaan. Fokus tulisan ini adalah membangun kepercayaan diri pada anak usia dini oleh orang tua. Sebagai figur utama orang tua berperan dalam membentuk kepribadian anak menjadi percaya diri atau minder. Peran orang tua dalam membangun kepercayaan diri anak adalah menjadi pendengar yang baik, menunjukkan sikap menghargai, memberi kesempatan untuk membantu, melatih kemandirian anak, membantu anak agar lebih optimis,memupuk minat dan bakat anak, mengajak memecahkan masalah, mencari cara untuk membantu sesama, memberi kesempatan anak berkumpul bersama orang dewasa dan mengarahkan agar dapat mempersiapkan masa depan.
\end{abstract}

Kata kunci: orang tua, kepercayaan diri, anak

\author{
Abstract \\ PARENTS' ROLE IN BUILDING EARLY CHILDHOOD \\ CONFIDENCE. A golden age on the development of the pre-school
}


age should be a serious concern among the main educator that is parents. Because this time is a time that is easy to form personality of children. This article tries to convince that with a confident personality then a child will become a successful person. This study focuses on building a confidence of early childhood by parents. As a major figure of the parents plays a role in shaping the personality of the child to be confident or insecure. The role of parents in building a child's confidence is being a good listener, showing respect, providing an opportunity to help, training the child's independence, helping children to be more optimistic, growing the child's interests, asking to solve a problem, looking for ways to help each other, allowing children to gather with adults and directing in order to prepare for the future.

Keywords: parents, confidence, children

\section{A. Pendahuluan}

Pendidikan anak usia dini telah banyak berkembang di masyarakat, baik yang ditumbuhkembangkan oleh instansi pemerintah maupun oleh masyarakat. Misalnya, Bina Keluarga Balita yang dikembangkan oleh BKKBN, Penitipan Anak oleh Depsos (dulu), TK oleh Depdiknas, TPA oleh Depag, dan Kelompok Bermain oleh masyarakat. Pendidikan anak usia dini terus mengalami peningkatan dari tahun ke tahun. Seperti jumlah anak padatahun 2002 yang berusia 0-6 tahun (28.311.300 orang), hanya 5,69 \% dilayani TK, $11 \%$ sudah masuk SD dan 52,25\% dibina melalui program Bina Keluarga Balita. Sisanya 30,06\% belum memperoleh pelayanan pendidikan.Namun, pada tahun 2005, UNESCO mencatat bahwa angka partisipasi PAUD di Indonesia menduduki posisi terendah di dunia (20\%). Fenomena yang sama juga terjadi di ASEAN, Indonesia tergolong rendah dibandingkan Vietnam, Filipina, Thailand, dan Malaysia. Saat ini sudah mulai tampak adanya perkembangan yang positif dalam bentuk pertumbuhan Kelompok Bermain dan Tempat Penitipan Anak yang pesat di masyarakat. Demikian pula dengan semakin kuatnya dukungan pemda, akademisi, praktisi dan birokrat. Hal ini terlihat dari pendidikan yang dilalui, yakni:

1. Pada jalur pendidikan formal, pendidikan anak usia dini berbentuk taman kanak-kanak (TK), Raudhatul Atfal (RA), atau yang sederajat. 
Peran Orang Tua dalam Membangun Kepercayaan diri...

2. Pada pendidikan nonformal, pendidikan anak usia dini berbentuk kelompok bermain (KB), taman penitipan anak (TPA) atau yang sederajat.

3. Pada jalur informal berupa pendidikan keluarga atau pendidikan yang diselenggarakan oleh lingkungan masyarakat.

Betapa pentingnya posisi keluarga dalam membentuk anak yang baik tersebut, sehingga undang-undang Nomor 20 Tahun 2003 tentang Sistem Pendidikan Nasional memasukkan pendidikan keluarga dan lingkungan yang dikemas dalam jalur pendidikan informal (pasal 27) sebagai bagian tidak terpisahkan dalam sistem pendidikan nasional.

Berkaitan dengan pendidikan anak usia dini, maka keluarga yang merupakan lingkungan pertama yang paling bertanggung jawab atas berlangsungnya kegiatan ini. Sebab, dari lingkungan keluargalah yang terdiri dari ayah, ibu, dan saudara-saudaranya seorang anak dapat mengisi usia emasnya, yakni hingga 5 tahun. Meskipun banyak teori yang mengarah pada pentingnya faktor bawaaan, dikenal dengan teori nativisme, dalam memberikan pengaruhpada seorang anak, tetapi juga dibantah oleh hadirnya teori empirismeyang mengusung bahwa seseorang dalam perkembangannya dipengaruhi oleh faktor lingkungan.

Namun, belum cukup juga untuk menjelaskan pengaruh yang paling besar bagi seseorang dalam membantu anak mengisi hari-harinya sehingga muncul teori ketiga yang dikenal dengan teori konvergensi yang berusaha menyatukan kedua teori tersebut dengan mengungkapkan bahwa faktor bawaan/genetika dan faktor lingkungan sangat berpengaruh bagi setiap orang dalam menjalani aktivitasnya, terutama bagi anak yang baru tumbuh dan berkembang (Rahman, 2009: 46-57).

Keluarga anak belajar di dalam melalui berbagai cara antara lain melalui imitasi, melakukan sesuatu atau mencoba dan mengalami (Einon, 2005). Lingkungan menyediakan sesuatu yang dibutuhkan anak, dan anak akan manfaatkan apa yang ditawarkan oleh lingkungan. 
Orang dewasa dapat melatih, menjelaskan, dan mengoreksi anak, atau menunjukkan sesuatu kepada anak. Oleh karena itu yang dapat dilakukan adalah membantu anak untuk melibatkan dan mendorong anak untuk mencoba dan mengalami. Anak mempunyai bakat atau kemampuan yang telah dibawa sejak lahir, namun bakat atau kemampuan tersebut tidak akan berkembang apabila tidak memperoleh rangsangan dari lingkungannya (Martani, 2012: 112 - 120). Perkembangan anak merupakan proses yang kompleks, terbentuk dari potensi diri anak yang bersangkutan dan lingkungan sekitarnya.Orang tua merupakan sosok yang paling berperan dalam menstimulasi perkembangan psikologis anak. Terkadang kita jumpai orangtua yang memperkuat kepercayaan diri anak menaruh harapan yang terlalu besar terhadap anaknya, tanpa disesuaikan dengan kemampuan anak itu sendiri. Akibatnya, anak dipaksa memenuhi harapan orang tua yang "tidak pada tempat-nya", sehingga anak sering kali menerima kritikan, mengalami rasa takut, dan merasakan kekecewaan. Hal ini dapat menyebabkan anak kehilangan rasa percaya dirinya. Apabila hal ini dibiarkan terus menerus terjadi, dampak dari kehilangan kepercayaan diri ini dapat berlanjut hingga anak beranjakdewasa.

Penjelasan tersebut dapat disimpulkan bahwa orang tua berperan penting dalam membangun kepercayaaan diri anak. Dengan pribadi percaya diri maka akan mudah mendapatkan masa depannya dengan gemilang. Oleh karena itu dengan alasan ini penulis ingin menyampaikan gagasan dengan judul "Peran Orang Tua dalam Membangun Kepercayaan Diri pada Anak Usia Dini”

\section{B. Pembahasan}

\section{Kepercaayaan Diri}

Kepercayaan diri merupakan satu aspek kepribadian yang paling penting pada seseorang. Kepercayaan diri merupakan atribut yang paling berharga pada diri seseorang dalam kehidupan bermasyarakat, dikarenakan dengan kepercayaan diri, seseorang mampu mengaktualisasikan segala potensi dirinya. Kepercayaan 
diri merupakan sesuatu yang urgen untuk dimiliki setiap individu. Kepercayaan diri diperlukan oleh siapa saja baik seorang anak maupun orangtua, dan secara individual maupun kelompok.

Kepercayaan diri merupakan suatu keyakinan yang dimiliki seseorang bahwa dirinya mampu berperilaku seperti yang dibutuhkan untuk memperoleh hasil seperti yang diharapkan (Bandura, 1977). Lauster (1978), mengungkapkan ciri-ciri orang yang percaya diri adalah: mandiri, tidak mementingkan diri sendiri, cukup toleran, ambisius, optimis, tidak pemalu, yakin dengan pendapatnya sendiri dan tidak berlebihan. Menurut Lauster (1978: 25), rasa percaya diri bukan merupakan sifat yang diturunkan (bawaan) melainkan diperoleh dari pengalaman hidup, serta dapat diajarkan dan ditanamkan melalui pendidikan, sehingga upaya-upaya tertentu dapat dilakukan guna membentuk dan meningkatkan rasa percaya diri. Dengan demikian kepercayaaan diri terbentuk dan berkembang melalui proses belajar di dalam interaksi seseorang dengan lingkungannya (Siska, dkk. 2003: 67 - 71). Sementara menurut Rogers (dalam Hall \& Lindzey, 1993: 45) konsep kepribadian yang paling penting adalah diri (self). Diri berisi persepsi-persepsi tentang sifat-sifat dari 'diri subjek' atau 'diri objek' dan persepsi-persepsi tentang hubungan-hubungan antara 'diri subjek' atau 'diri objek' dengan orang-orang lain dan dengan berbagai aspek kehidupan beserta nilai-nilai yang melekat pada persepsi-persepsi ini. Hal ini menunjukkan bahwa untuk dapat berinteraksi sosial dengan baik diperlukan pemahaman tentang diri sendiri dan keyakinan akan kemampuan diri sendiri. Individu yang yakin akan kemampuan dirinya merupakan indikasi dari rasa percaya diri seseorang. Hal ini didasari oleh apa yang dikatakan Hakim (2002: 4) bahwa rasa percaya diri bisa dikatakan sebagai suatu keyakinan seseorang terhadap segala aspek kelebihan yang dimilikinya dan keyakinan tersebut membuatnya merasa mampu untuk bisa mencapai berbagai tujuan di dalam hidupnya.

Balke (2003: 99) mendefinisikan kepercayaan diri sebagai kemauan untuk mencoba sesuatu yang paling menakutkan bagi anda dan anda yakin bahwa anda mampu mengelola sesuatu yang timbul. 
Artinya bahwa kepercayaan diri dapat dikaitkan dengan kemampuan atau keberanian dalam mengambil resiko, keputusan, maupun tantangan yang bukan hanya membawa resiko fisik melainkan juga resiko psikologis karena timbul perasaan yang pasti tentang dirinya.

\section{Ciri-ciri Pribadi Percaya Diri}

Karakteristik (Ciri-Ciri) Kepercayaan Diri Pemahaman tentang hakekat percaya diri akan lebih jelas jika seseorang melihat secara langsung berbagai peristiwa yang dialami oleh dirinya sendiri atau orang lain. Berdasarkan berbagai peristiwa atau pengalaman, bisa dilihat gejala-gejala tingkah laku seseorang yang menggambarkan adanya rasa percaya diri atau tidak. Berikut akan dikemukakan beberapa pendapat mengenai ciri-ciri (karakteristik) kepercayaan diri atau individu yang memiliki kepercayaan diri yang baik. Selain itu sebagai perbandingan juga akan dikemukakan pendapat mengenai ciri-ciri individu yang kurang memiliki kepercayaan diri. Berdasarkan pengamatan mendalam yang dilakukan Hakim (2002: 6), akan terlihat adanya ciri-ciri tertentu dari orang-orang yang mempunyai rasa percaya diri yang tinggi sebagai berikut:

1. Selalu bersikap tenang dalam menghadapi sesuatu

2. Mempunyai potensi dan kemampuan yang memadai

3. Mampu menetralisasi ketegangan yang muncul di dalam berbagai situasi

4. Mampu menyesuaika $\mathrm{n}$ diri dan berkomunikasi di berbagai situasi

5. Memiliki kondisi mental dan fisik yang cukup menunjang penampilannya

6. Memiliki kecerdasan yang cukup

7. Memiliki tingkat pendidikan formal yang cukup

8. Memiliki keahlian atau keterampilan lain yang menunjang kehidupannya.

9. Memiliki kemampuan bersosialisasi

10. Memiliki latar belakang pendidikan keluarga yang baik

11. Memiliki pengalaman hidup yang menempa mentalnya menjadi kuat dan tahan di dalam menghadapi berbagai cobaan hidup 
Peran Orang Tua dalam Membangun Kepercayaan diri...

Selalu bereaksi positif dalam menghadapi berbagai masalah, misalnya dengan tetap tegar, abar, dan tabah dalam menghadapi persoalan hidup. Dengan ini, adanya masalah hidup yang berat justru semakin memperkuat rasa percaya diri seseorang.

Sedangkan ciri-ciri rasa percaya diri yang kurang sebagai berikut (Hakim, 2002):

1. Mudah cemas dalam menghadapi persoalan dengan tingkat kesulitan tertentu

2. Memiliki kelemahan atau kekurangan dari segi mental, fisik, sosial, atau ekonomi

3. Sulit menetralisasi timbulnya ketegangan di dalam suatu situasi

4. Gugup dan terkadang bicara gagap

5. Memiliki latar belakang pendidikan keluarga yang kurang baik

6. Memiliki perkembangan yang kurang baik sejak masa kecil.

7. Kurang memiliki kelebihan pada bidang tertentu dan tidak tahu bagaimana cara

8. Mengembangkan diri untuk memiliki kelebihan tertentu

9. Sering menyendiri dari kelompok yang dianggapnya lebih dari dirinya

10. Mudah putus asa

11. Cenderung tergantung pada orang lain dalam mengatasi masalah

12. Pernah mengalami trauma

13. Sering bereaksi negatif dalam menghadapi masalah, misalnya dengan menghindari tanggung jawab atau mengisolasi diri, yangmenyebabkan rasa tidak percaya dirinya semakin buruk.

Individu yang percaya diri dapat diindikasi memiliki perasaan yang adekuat terhadap tindakan yang dilakukan, memiliki ketenangan sikap, dapat berkomunikasi dengan baik, kemampuan untuk bersosialisasi, merasa optimis, dapat mengendalikan perasaannya, percaya akan kompetensi/kemampuan diri, dan memiliki internal locus of cont rol (memandang keberhasilan atau kegagalan, tergantung 
dari usaha diri sendiri dan tidak mudah menyerah pada nasib atau keadaan serta tidak tergantung/mengharapkan bantuan orang lain.

Afiatin dan Martaniah (1998: 67-69) merumuskan beberapa aspek dari Lauster dan Guilford yang menjadi ciri maupun indikator dari kepercayaan diri yaitu :

1. Individu merasa adekuat terhadap tindakan yang dilakukan. Hal ini didasari oleh adanya keyakinan tehadap kekuatan, kemampuan, dan keterampilan yang dimiliki. Ia merasa optimis, cukup abisius, tidak selalu memerlukan bantuan orang lain, sanggup bekerja keras, mampu menghadapi tugas dengan baik dan bekerja secara efektif serta bertanggung jawab atas keputusan dan perbuatannya.

2. Individu merasa diterima oleh kelompoknya. Hal ini dilandasi oleh adanya keyakinan terhadap kemampuannya dalam berhubungan sosial. Ia merasa bahwa kelompoknya atau orang lain menyukainya, aktif menghadapi keadaan lingkungan, berani mengemukakan kehendak atau ide-idenya secara bertanggung jawab dan tidak mementingkan diri sendiri.

3. Individu memiliki ketenangan sikap. Hal ini didasari oleh adanya keyakinan terhadap kekuatan dan kemampuannya. Ia bersikap tenang, tidak mudah gugup, cukup toleran terhadap berbagai macam situasi.

Kepercayaan diri akan memberikan suatu dampak kepada diri individu. Rasa percaya diri memberikan dampak dampak positif pada hal-hal berikut ini :

1. Emosi, individu yang memiliki rasa percaya diri yang tinggi akan lebih mudah mengendalikan dirinya di dalam suatu keadaan yang menekan.

2. Konsentrasi, seorang individu akan lebih mudah memusatkan perhatiannya pada hal tertentu tanpa rasa terlalu khawatir.

3. Sasaran, individu cenderung mengarahkan pada sasaran yang cukup menantang, karenanya ia juga akan mendorong dirinya untuk berupaya labih baik.

4. Usaha, individu tidak mudah patah semangat atau frustrasi 
Peran Orang Tua dalam Membangun Kepercayaan diri...

dalam berupaya meraih cita-citanya dan cenderung tetap berusaha kuat secara optimal sampai usahanya berhasil.

5. Strategi, individu mampu mengembangkan berbagai strategi untuk memperoleh hasil usahanya.

6. Momentum, seorang individu akan menjadi lebih tenang, ulet, tidak mudah patahsemangat, terus berusaha, mengembangkan dan membuka peluang bagi dirinya. (Yulianto, F dan Fuad Nashori,2006: 55).

\section{Faktor-faktor yang Mempengaruhi Kepercayaan Diri}

Uraian di atas menunjukkan bahwa kepercayaan diri tidak muncul begitu saja dalam diri seorang. Ada proses tertentu di dalam diri seseorang sehingga terjadilah pembentukan kepercayaan diri. Secara garis besar, menurut Hakim (2002: 6) terbentuknya kepercayaan diri yang kuat terjadi melalui proses sebagai berikut:

1. Terbentuknya kepribadian yang baik sesuai dengan proses perkembangan yang melahirkan kelebihan-kelebihan tertentu

2. Pemahaman seseorang terhadap kelebihan-kelebihan yang dimilikinya dan melahirkan keyakinan kuat untuk bisa berbuat segala sesuatu dengan memanfaatkan kelebihankelebihannya.

3. Pemahaman dan reaksi positif seseorang terha dap kelemahankelemahan yang dimilikinya agar tidak menimbulkan rasa sulit menyesuaikan diri.

Pengalaman di dalam menjalani berbagai aspek kehidupan dengan menggunakan segala kelebihan yang ada pada dirinya.

\section{Anak Usia Dini}

Pada saat anak usia balita, pendidikan yang mereka peroleh bertumpu pada pendidikan orang tua. Namun, setelah anak usia TK, pendidikan yang diterima dari orang tua dan juga guru. Untuk yang pertama kalinya, mereka memperoleh pendidikan dari dua sumber, dari dua pendidik, dari dua tempat dan suasana yang berbeda (Syafei, 2006: 38). 
Menurut Cowley (2011: 207-208), ada beberapa prinsip utama yang dapat diterapkan ketika mengajar anak usia dini.

1. Sekolah mungkin terasa membingungkan atau bahkan sangat menakutkan bagi mereka

2. Masih sering kali terikat dengan orang tua atau pengasuh mereka; belajar untuk percaya diri dan independe merupakan kunci dari tahap ini

3. Mereka berada di tahap awal dalam mempelajari keterampilan pribadi, sosial dan emosional, seperti empati dan mengendalikan amarah mereka

4. Pola dari seluruh jenjang pendidikan anak sedang terbentuk

5. Kesempatan untuk menetapkan kebiasaan baik, pola, dan rutinitas, bukan sifat negatif

6. Idealnya adalah mencontohkan perilaku yang baik, menjelaskan batasan yang jelas, dan memberikan banyak penghargaan

7. Orang tua seharusnya tidak menakut-nakuti anak kecil untuk berperilaku baik

8. Setiap intervensi yang dibuat sekarang akan memiliki dampak yang lebih besar daripada yang digunakann nanti

9. Pengajar atau guru menghabiskan lebih banyak waktu dengan anak secara individu sehingga dapat memiliki dampak yang lebih besar terhadap mereka daripada terhadap siswa yang lebih tua

10. Bagi anak dengan latar belakang pengasuhan yang buruk, guru taman kanak-kanak atau sekolah dasar mungkin merupakan orang dewasa pertama yang mencontohkan perilaku baik

11. Seorang anak yang tidak pernah diajari tentang batasan mungkin memerlukan waktu untuk mengikuti rutinitas kelas.

\section{Peran Orang Tua dalam Membagun Kepercayaaan Diri Anak Usia Dini}

Untuk mampu membangun rasa percaya diri, maka tugas orang tua adalah sebagai berikut: 
1. Jadilah pendengar baik

Sesibuk apapun, ketika ia meminta perhatian Anda, cobalah untuk mendengarkan dengan sungguh-sungguh. Tinggalkan pekerjaan Anda, tatap matanya, dan biarkan ia bicara. Mengabaikannya akan membuat ia merasa tidak berharga, tidak layak untuk diperhatikan, dan hal itu mengoyak rasa percaya dirinya.

2. Tunjukkan sikap menghargai

Sekalipun keinginannya mungkin tidak bisa Anda penuhi. Memaksa anak untuk selalu menuruti keinginan Anda akan merusak rasa percaya dirinya.

3. Biarkan ia membantu.

Meski masih kecil, ia sudah bisa kok, membawakan kantung belanjaan Anda yang tidak terlalu berat. Rasa bangga karena bisa membantu Anda akan memupuk rasa percaya dirinya.

4. Biarkan ia melakukan sendiri apa yang sudah bisa ia lakukan.

Kalau ia mau mengambil lauk sendiri di meja makan saat makan bersama, mengapa harus dilarang? Justru sebaliknya, dukung dia meski ia terlihat masih kikuk saat melakukannya. Intinya, selain perhatian dan dukungan, berikan padanya kebebasan untuk melakukan apa yang sudah bisa ia lakukan, Ma. Semua itu akan membuat ia tahu, Anda percaya ia bisa, dan ia memang bisa.

5. Memilah pujian anda

Tentu saja, anak kecil butuh banyak motivasi, apakah ketika mereka belajar merangkak, melempar bola, atau membuat gambar lingkaran. Tapi anak akan menjadi begitu terbiasa mendengar kata "Adik pintar!" sehingga dia bisa kesulitan untuk benar-benar menyadari ketika pencapaian yang dia lakukan memang patut dirayakan. Anak juga bisa merasakan ketika orang tua melebih-lebihkan ("Wah, itu istana balok paling indah yang pernah Mama lihat!") dan akan mulai 
mengabaikan pujian yang Anda berikan. "Jangan puji anak jika dia melakukan sesuatu yang memang sudah seharusnya dia lakukan. Ketika dia menggosok gigi atau memasukkan baju kotornya ke keranjang cucian misalnya, ucapan "terima kasih" sudah cukup. Orang tua mencoba untuk memberinya tanggapan balik yang spesifik: Daripada berkata bahwa gambar yang dia hasilkan sangat menawan, Anda bisa mengatakan bahwa warna ungu yang dia pakai pada gambar tersebut indah dilihat.

6. Jangan langsung "menyelamatkan" si kecil

Adalah hal yang alami jika Anda selalu ingin menghindarkan si kecil agar tidak terluka, tidak merasa takut, atau tidak berbuat kesalahan. Tapi ketika orang tua menginterupsi keadaan - mencoba membuat anak mendapat undangan pesta ulang tahun yang sebenarnya tidak diundang, atau memaksa pelatih sepakbola untuk memberi anak lebih banyak kesempatan bermain di lapangan orang tua tidak membantunya. Anak perlu tahu bahwa kalah, atau jatuh adalah hal yang wajar.. Anak belajar menjadi sukses ketika mereka berhasil mengalahkan rintangan, bukan karena orang tua yang membantunya menyingkirkan rintangan tersebut. "Adalah hal yang penting bagi anak usia muda untuk mendapat kesempatan bermain dan menerima risiko tanpa merasa bahwa orang tua mereka akan mengeritik atau membetulkan mereka jika melakukan kesalahan. Bahkan mendorong para orang tua untuk sengaja melakukan kesalahan kecil di hadapan anak. "Melihat orang tua melakukan kesalahan dan tidak menjadikan kesalahan tersebut sebagai hal yang luar biasa akan membuat anak merasa jauh lebih nyaman."

7. Fokus pada "gelas setengah penuh"

Jika anak memiliki kecenderungan untuk merasa rendah diri setelah mengalami suatu kekecewaan, bantu anak untuk merasa lebih optimis menghadapinya. Daripada menawarkan pencerahan semu seperti, "Yah, paling tidak masih ada sisi positifnya," mendukung anak untuk memikirkan satu 
cara spesifik untuk membuat situasinya membaik dan dapat membantu mencapai tujuan yang diinginkan. Jika kemampuan membaca anak tertinggal dibanding teman satu kelasnya, jelaskan bahwa semua orang belajar dengan kecepatannya masing-masing, dan mengajak anak untuk menghabiskan lebih banyak waktu belajar membaca bersama. Jika anak sangat terluka ketika tidak berhasil mendapat ranking atau bintang kelas, jangan katakan, “Tapi menurut Mama kamu adalah bintang." Sebaliknya, katakan, "Mama mengerti kamu sangat kecewa. Yuk kita buat program belajar baru yang bisa meningkatkan peluang kamu menjadi juara kelas pada semester berikutnya."

h. Memupuk minat dan bakat anak

Kenalkan anak pada beragam aktivitas, dan beri dorongan agar dia menemukan satu jenis aktivitas yang sangat disukainya. Anak yang memiliki hasrat akan sesuatu -apakah itu kecintaan pada dinosaurus atau kegiatan memasak - akan merasa bangga pada pencapaian mereka dan kemungkinan besar akan lebih sukses di berbagai area lain dalan kehidupannya. Hobi yang unik akan sangat membantu anak yang kurang bisa membaur di sekolah. Anda juga bisa membantu anak untuk menunjukkan hobi dan bakatnya pada anak yang lain sehingga dia menjadi lebih mudah berteman. Misalnya, jika anak senang menggambar tapi kebanyakan teman sekelasnya lebih menyenangi olahraga, anjurkan anak untuk menggambar dengan tema olahraga. Atau dia bisa membuat satu koleksi buku berisi gambar-gambar aktivitas olahraga yang bisa diperlihatkan pada teman sekelas. "Ada kalanya orang tua dan guru perlu bekerja sama mencari cara untuk membantu agar anak menjadi menonjol di kelas.

9. Mengajak memecahkan masalah

"Anak akan membangun kepercayaan diri ketika mereka berhasil bernegosiasi untuk mendapatkan apa yang diinginkan. Orang tua bisa mengajarkan anak yang masih sangat kecil 
untuk mencoba memecahkan masalah sendiri. Kuncinya adalah: tidak banyak bicara. Jika anak menghampiri orang tua dengan keluhan bahwa temannya merebut mobil-mobilan kesayangannya ketika bermain di taman, tanyakan pada anak, cara seperti apa yang bisa dilakukan agar dia mendapatkan kembali mainannya. Bahkan jika ide yang pertama terlontar dari mulut si kecil adalah menarik paksa mainan itu dari tangan temannya, tanyakan pada anak, apa yang mungkin akan terjadi selanjutnya jika dia melakukan hal itu. Lalu tanyakan, "Bisa Adik mencari cara lain untuk mendapatkan kembali mobil-mobilan itu tanpa perlu berantem?” Dalam salah satu penelitian Dr. Shure mengenai situasi ini, seorang anak berusia 4 tahun mengeluarkan ide brilian yang sangat dewasa, yaitu dengan berkata pada si perebut mainan, "Kamu akan bisa lebih bersenang-senang jika bermain mobil-mobilan bersamaku daripada jika kamu bermain sendirian."

10. Mencari cara untuk membantu sesama

Ketika anak merasa bahwa mereka telah berhasil melakukan suatu perubahan-apakah itu sekadar mengoper kue pada teman di meja sebelah, atau membawa sekeranjang buah untuk diberikan ke panti jompo- anak akan menjadi lebih percaya diri. Adalah hal yang baik jika anak diberi satu tanggung jawab mengurus rumah (menyapu atau merapikan tempat tidur), tapi akan lebih membangun kepercayaan diri pada anak usia muda jika mereka membantu dalam suatu kegiatan ("Mama benar-benar butuh bantuan kakak"). "Anak akan bisa melihat langsung bahwa tugas orang dewasa membutuhkan usaha yang keras, dan akan menjadi lebih mudah bagi anak tersebut jika di kemudian hari dia harus melakukan tugas yang pernah dia lakukan bersama Anda.

11. Memberi kesempatan anak berkumpul bersama orang dewasa

Anak-anak senang bergaul dengan teman sebaya tapi juga penting bagi anak untuk berada di antara orang dewasa. Menghabiskan waktu dengan orang yang lebih tua akan 
Peran Orang Tua dalam Membangun Kepercayaan diri...

memperluas cakrawala anak, membuatnya mampu berinteraksi dengan orang dewasa didekatnya, dan memberi sudut pandang pemikiran yang berbeda. Peneliti juga telah menemukan bahwa memiliki hubungan dekat dengan satu orang dewasa guru, paman, babysitter, atau orang tua sahabat- membuat anak menjadi lebih ulet menghadapi hidup.

12. Berkhayal mengenai masa depan

Jika anak bisa membayangkan melakukan suatu hal berguna saat mereka dewasa, anak akan merasa lebih percaya diri di masa kanak-kanaknya. Ajak anak berdiskusi mengenai bagaimana orang tua, dan orang dewasa lain (yang dia kenal) memilih profesi yang sekarang ditekuni. Bahkan jika dia mengubah cita-citanya, yang paling penting adalah dia sudah memikirkan tujuannya di masa depan.

\section{Simpulan}

Orang tua memegang peranan yang sangat penting dalam membentuk karakter seorang anak. Salah satu upaya dalam pembentukan karakter tersebut adalah membangun kepercayaan diri pada anak. Peran orang tua dalam membangun kepercayaan diri anak diantaranyaadalah menjadi pendengar yang baik, menunjukkan sikap menghargai, memberi kesempatan untuk membantu, melatih kemandirian anak, memilah pujian orang tua terhadap anak, membantu anak agar lebih optimis, memupuk minat dan bakat anak, mengajak memecahkan masalah, mencari cara untuk membantu sesama, memberi kesempatan anak berkumpul bersama orang dewasa dan mengarahkan agar dapat mempersiapkan masa depan. 


\section{DAFTAR PUSTAKA}

Bandura, A..1977. Social Learning Theory. New Jersey: Prentice Hall Inc.

Cowley, Sue. 2011. Panduan Manajemen Perilaku Siswa. Jakarta: Erlangga

Ellen, Balke. 2003. Know Yourself. Diterjemahkan oleh Hari Wahyudi. Jakarta: Elex Media Komputindo.

Hakim, Thursan . 2002. Mengatasi Rasa Tidak Percaya Diri. Yogyakarta: Torren Book

Hall, L dan Lindzey,G.1993. Teori-teori Psikodinamik (klinis) Ahli Bahasa: Supratiknya.Yogyakarta:kanisius

Lauster. 1978. Tes Kepribadian. DH Bulo. Jakarta: Bumi Aksara.

Saputro, Niko Dimas dan Miftahun Ni'mah Suseno, 2010. Hubungan Antara Kepercayaan Diri Dengan Employability Pada Mahasiswa.JurnalPendidikan Penabur. No.15/Tahun ke-9/Desember.Malang: Universitas Muhammadiyah MalangFakultas Psikologi.

Siska, Sudardjo dan Esti Hayu Purnamaningsih. 2003.Kepercayaan Diri dan Kecemasan Komunikasi Interpersonal pada Mahasiswa. Jurnal PsikologiNO. 2, 67 - 71 ,ISSN : 0215 - 8884. Yogyakarta: Universitas Gadjah Mada.

Syafei, M. Sahlan. 2006. Bagaimana Anda Mendidik Anak. Bogor: Ghalia Indonesia.

Winarni, Reny. 2013. Kepercayaan Diri Dengan Kecemasan Komunikasi Di Depan Umum Pada Mahasiswa.Jurnal Online Psikologi Vol. 01 No. 02, Thn. 2013.

Wisjnu, Martani. 2012. Metode Stimulasi dan Perkembangan Emosi. 112 JURNAL PSIKOLOGI VOLUME 39, NO. 1, JUNI 2012: 112 - 120 Yogyakarta: Universitas Gadjah MadaFakultas Psikologi.

Yulianto,Fitri dan Fuad Nashori. 2006. Kepercayaan Diri Dan Prestasi Atlet Tae Kwon Do Daerah Istimewa Yogyakarta.Jurnal PsikologiSemarang, Universitas Diponegoro Vol.3 No. 1, Juni 2006. 